\title{
Central Asia's Ili River Ecosystem as a Wicked Problem: Unraveling Complex Interrelationships at the Interface of Water, Energy, and Food
}

\author{
Steven G. Pueppke ${ }^{1,2,3, *}$, Sabir T. Nurtazin ${ }^{4}$, Norman A. Graham ${ }^{2,5}$ and Jiaguo Qi $^{3}$ \\ 1 Department of Plant, Soil, and Microbial Sciences, Michigan State University, 1066 Bogue Street, \\ East Lansing, MI 48824, USA \\ 2 Center for European, Russian, and Eurasian Studies, Michigan State University, 427 North Shaw Lane, \\ East Lansing, MI 48824, USA; ngraham@msu.edu \\ 3 Center for Global Change and Earth Observations, Michigan State University, 1405 South Harrison Road, \\ East Lansing, MI 48824, USA; qi@msu.edu \\ 4 Faculty of Biology and Biotechnology, Al-Farabi Kazakh National University, 71 Al-Farabi Avenue, \\ 050040 Almaty, Kazakhstan; iklasovmargulan@gmail.com \\ 5 James Madison College, Michigan State University, 842 Chestnut Road, East Lansing, MI 48824, USA \\ * Correspondence: pueppke@msu.edu; Tel.: +1-269-888-1150
}

Received: 13 January 2018; Accepted: 17 April 2018; Published: 24 April 2018

\begin{abstract}
The Ili River originates in the mountains of Xinjiang, China, and flows across an increasingly arid landscape before terminating in Kazakhstan's Lake Balkhash, which has no outlet to the ocean. The river has been extensively impounded and diverted over the past half century to produce hydroelectric power and food on irrigated land. Water withdrawals are increasing to the extent that they are beginning to threaten the ecosystem, just as it is becoming stressed by altered inflows as glaciers retreat and disappear. If the Ili River ecosystem is to be preserved, it is crucial that we thoroughly understand the spatial and temporal nuances of the interrelationships between water, energy, and food-and the vulnerability of these components to climate change. The ecosystem has all of the characteristics of a classically-defined "wicked problem", and so it warrants treatment as a complex and dynamic challenge subject to changing assumptions, unexpected consequences, and strong social and economic overtones. Research should thus focus not just on new knowledge about the water, energy, or food component, but on advancing our understanding of the ecosystem as a whole. This will require the participation of interdisciplinary teams of researchers with both tacit and specialized knowledge.
\end{abstract}

Keywords: Ili River; Kapchagai dam and reservoir; Lake Balkhash; Central Asia; water-energy-food; wicked problems

\section{Introduction}

Endorheic river basins are among the Earth's most threatened features. Water in these closed hydrological systems has no pathway of egress to the sea, and so it flows into so-called terminal lakes that, as their name implies, lack outlets. These water bodies, the rivers that sustain them and, indeed, the fragile ecosystems surrounding them, can be easily disrupted by diversion of water for human uses. Such anthropogenic pressures are becoming acute in Central Asia, the region centered on the five former Soviet republics of Turkmenistan, Tajikistan, Kazakhstan, Kyrgyzstan, and Uzbekistan [1]. It is here, where the climate is arid, evaporation a significant factor, and the vast majority of all waterways fail to reach the sea, that large volumes of water are being redistributed to meet human needs. 
These stresses are being aggravated by two additional factors. One, the elevated mean temperatures and altered rain and snowfall patterns associated with climate change [2], is of growing environmental concern and will have wide-reaching and long-term impacts across Central Asia [3,4]. The other is geopolitical and traces back to the 1991 dissolution of the Soviet Union, which superimposed a web of new international borders onto the map of a region that had been subject to a centrally-planned economy within the boundaries of one single country [5]. These two developments reinforce one another, setting the stage for region-wide water conflicts.

The near complete destruction of the Aral Sea, a terminal lake straddling the border of Uzbekistan and Kazakhstan, serves as a well-studied example [6] of the environmental damage that can be triggered by ill-advised water diversion from Central Asia's endorheic ecosystems (in this case, a process begun under the Soviet Union as a tactic to increase yields of cotton for export). The Aral Sea and other compromised water basins across the entire region have long drawn the attention of researchers, policymakers, international agencies, and others, yet the underlying challenge persists: What is the best means to balance the demands that economic priorities place on Central Asia's water with those necessary to ensure stable performance of the underlying ecosystems?

Here we argue for a data-driven perspective to consider this challenge, one that moves beyond sector-centric approaches and seeks a more balanced and integrative analysis. We draw attention to the complex, climate-dependent entanglements between the water component, which has received most past attention, and two key, interrelated drivers: generation of energy and provision of food [7]. Integrative approaches that factor in such complexities are imperative when the underlying challenge exhibits, as it does here, the hallmark characteristics of a wicked problem [8]. We focus on the ecosystem defined by the Ili River and its terminal water body, Lake Balkhash. This ecosystem is ideal as a case study. Threatened, yet still relatively unharmed in comparison to nearby ecosystems, such as those defined by the Syr Darya and Amu Darya rivers [9], it is subject to the panoply of environmental constraints and accessory complications that characterize the region $[1,10]$. We especially want to identify priority knowledge gaps at the complex interfaces between components of this ecosystem. With these insights in hand, it should be possible to engage research expertise to generate the most-needed information on the underlying environmental resources.

\section{The Ili River Ecosystem}

The 1439-km long Ili River and its 130,000 $\mathrm{km}^{2}$ drainage basin are shared by two sovereign nations, China and Kazakhstan [11,12]. Most of the Ili's waters trace their origins to snow and glacial runoff from Northwestern China's Tien Shan Mountains: the Borohoro Range to the northeast and the Halik Range to the southeast. The water coalesces in the lowlands between the flanking mountain ranges to form the Tekes and the Künes rivers, which merge and then are joined by the Kash River and smaller streams to form the main artery of the Ili (Figure 1). The Ili River descends west through China's Ili Kazakh Autonomous Prefecture, nourishing the fertile Ili River Valley, which gradually opens into a broad plain before crossing the international border. Several smaller streams, including the main tributary within Kazakhstan, the Charyn River, enter from the south and merge with the Ili as it meanders in a westward and then northwestwardly direction across an increasingly arid basin that can sustain little more than shrubs and grasslands [1,13]. The river's 815-km Kazakhstan course has, for the past 50 years, been interrupted by the largest artificial feature along its pathway, the Kapchagai dam and reservoir (Figure 1).

The riverine landscape changes when, roughly 100-150 km upstream from Lake Balkhash, the Ili separates into a series of ever changing channels that shape a marshy, $8000 \mathrm{~km}^{2}$ delta $[14,15]$. These wetlands, which overlie the region's saline soils [16], comprise the most unique natural aquatic feature of the Ili River, supporting a composite of meadows, reeds, salt-loving vegetation, and the tugai, a characteristic mixed riparian community of trees and shrubs [17]. The lake and estuary harbor a rich and diverse fauna and define a Wetland of International Importance as defined by the Ramsar Convention. Lake Balkhash is currently the largest freshwater lake in Central Asia, a status that was 
made possible by the shrinkage of the Aral Sea over recent decades. An arc-shaped body of water with a surface area of about 16,400 km², the lake is about $600 \mathrm{~km}$ in length and between 4 and $74 \mathrm{~km}$ in width. It is naturally subdivided into a relatively deep, brackish eastern portion that is fed by several minor rivers, and a shallower, less salty western portion fed by the Ili River [11,17].

Prior to anthropogenic disturbances, the Ili River transported about 10 million tons of sediment per year, half deposited in the delta and half swept into the lake [11]. Yearly inflows of water from the river, estimated to average about $12 \mathrm{~km}^{3}$, represented $80 \%$ of the mean annual discharge into Lake Balkhash, the other water entering from several smaller, less significant streams to the north, as well as small amounts of precipitation and subsurface flows [18]. Inflows were nominally balanced by evaporation, the only significant means by which water can naturally leave the lake [19], but natural periodic fluctuations in the lake level are common [17]. These are attributable to Central Asia's geography, which creates a strongly continental climate characterized by extremes in weather [14]. Geography also renders the Ili River ecosystem highly vulnerable to climate change [20-22], which has caused one in four of the glaciers charging the river to disappear during the past 50 years and the others to recede [23].

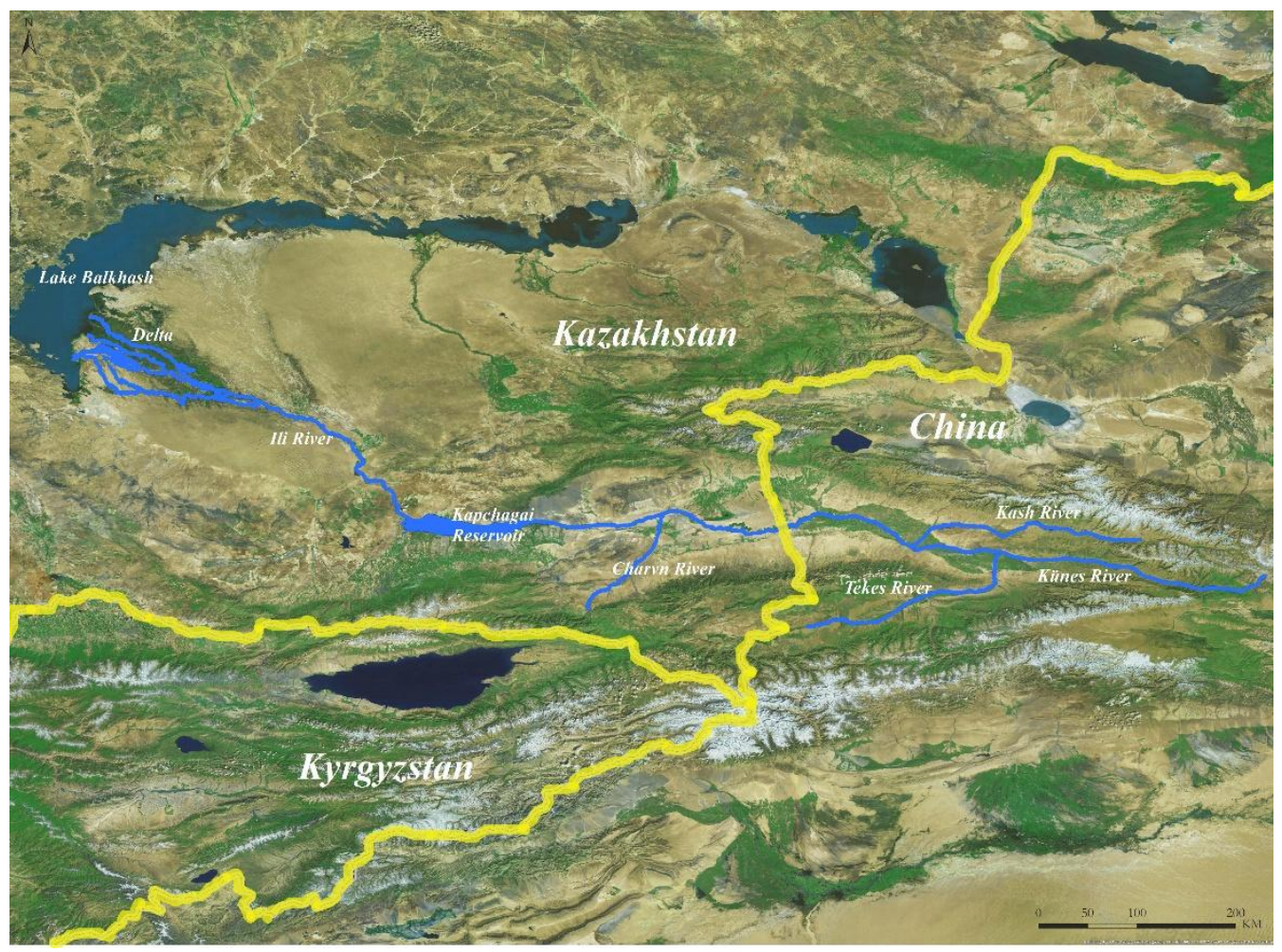

Figure 1. The Ili River ecosystem of Kazakhstan and China showing Lake Balkhash, the Ili River delta, Kapchagai Reservoir, and the three feeder rivers that form the Ili River in China. International borders are in yellow.

Fluctuations and vulnerability to natural forces are inherent features of the Ili-Balkhash ecosystem [24], but anthropogenic threats are not. Key among the latter is the degree to which water has become enmeshed in the quest by regional powers to achieve energy and food security. Although these demands are often interpreted solely in terms of hydropower and irrigation, as discussed below, they are marked by considerable nuance and complexity. 


\section{Interrelationships between Water, Energy, and Food in the Ili River Ecosystem}

\subsection{China}

Food production in the Ili River ecosystem is restricted to mountainsides and upstream river valleys in China and to the estuary and zones of irrigated desert along the lower reaches of the river and its feeder streams in Kazakhstan (lack of rainfall in the arid Kazakh zone precludes cultivation of crops and sharply restricts any sort of animal husbandry in non-irrigated areas). The Chinese portion of the ecosystem lies within the boundaries of the Ili Kazakh Autonomous Prefecture, a land area of $56,000 \mathrm{~km}^{2}$ with more than three million inhabitants. Here the lowlands adjacent to the Ili River and its tributaries enjoy an abundance of sunshine and between 100 and 200 frost-free days a year, and so they are well suited for habitation and food production (Figure 2). The region's pastures and montane meadows traditionally supported pastoral agriculture [25]. Herds of cattle, horses, and sheep were driven up and down the mountainside by nomadic peoples as the productivity of grazing sites changed with the seasons.

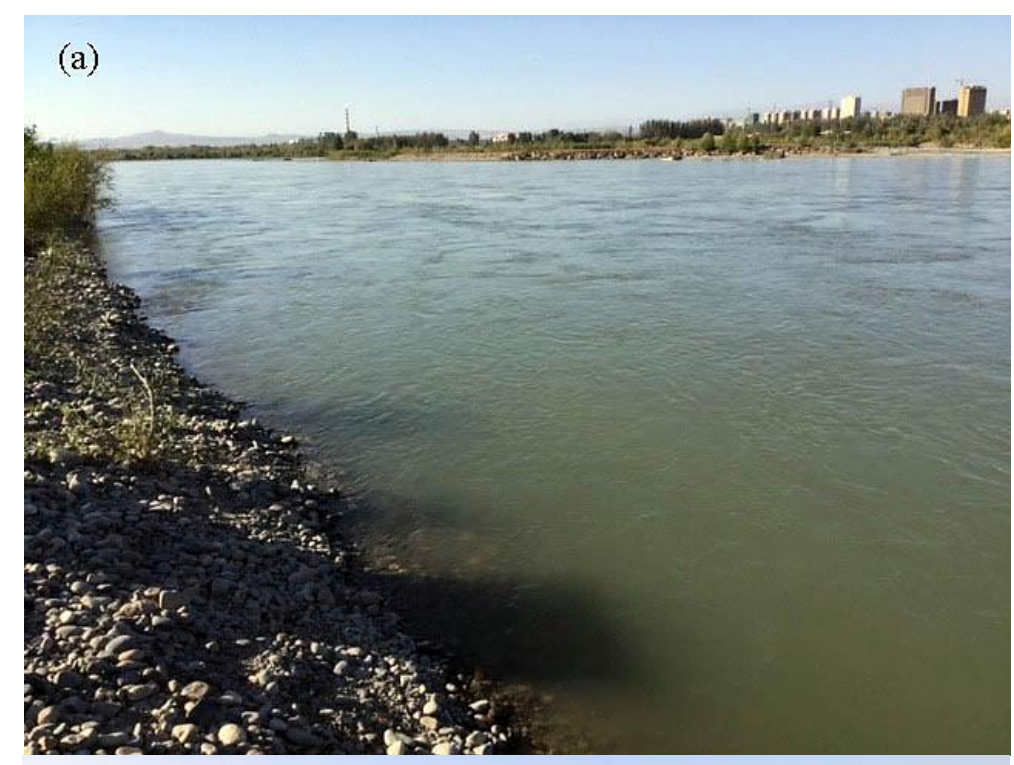

(b)

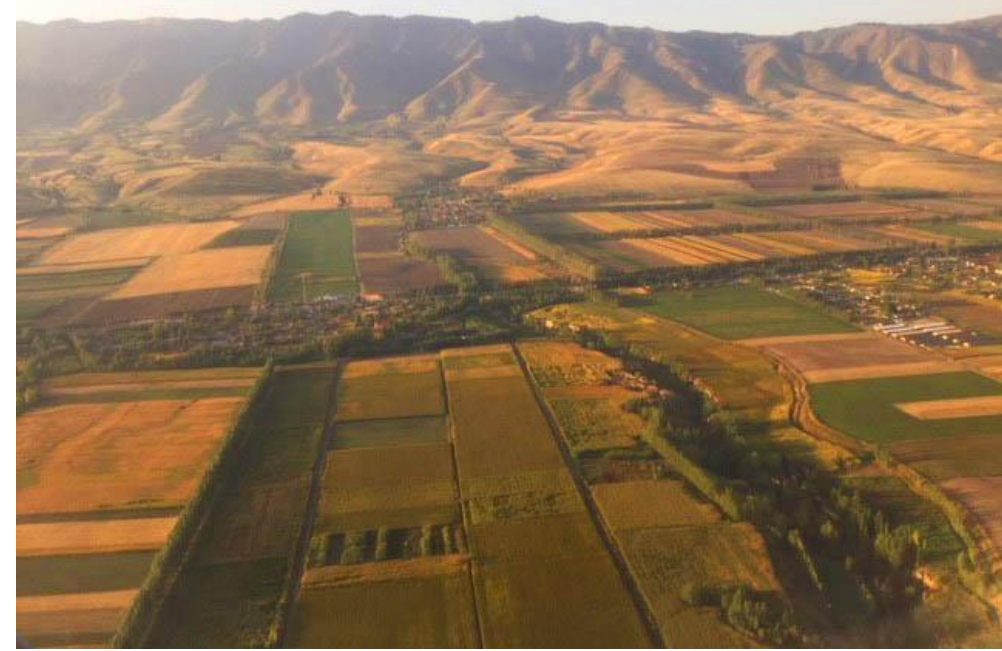

Figure 2. (a) The Ili River as it flows westward past the city of Yining; and (b) agricultural fields in the upper valley along the Künes River. Both photos were taken in September 2017. 
This began to change with the advent of crop-based agriculture (primarily wheat) during the 1750 s, a transition that coincided with the appearance of the first irrigation ditches along the upper Ili $[26,27]$. The subsequent expansion of croplands in the valley along the river accelerated after the founding of the People's Republic of China in 1949 [28] and has proceeded in lockstep with the steady proliferation of infrastructure to divert water. By the mid-1960s Mao Zedong's Great Leap Forward had prioritized crop production to the extent that fully half of the valley's cropland, nearly 290,000 ha, was irrigated through a series of canals and ditches to produce field crops such as rapeseed, rice, millet, and soybean $[25,26]$.

Although official statistics indicate that irrigated areas were not enlarging during the late twentieth century, analysis of satellite imagery confirms that newly-irrigated cropland along the Ili and its feeder streams expanded at the rate of 4000 to 6000 ha per year during this period, reaching a total of 600,000 to 650,000 ha by $2000[28,29]$. In spite of overgrazing on the residual lands that remain available for animal husbandry, the area of irrigated land has further increased, nearly doubling between 2000 and 2014 [30-32]. Proposals to divert water from the Ili River ecosystem to irrigate cotton in adjacent Chinese river basins would abstract even more of the Ili River's flow [33,34]. These were proposed early in the century but have not yet been implemented.

Fish capture along the Chinese reaches of the upper Ili River is only 100-300 tons per year [35,36], and so it is not surprising that land-based production of food crops such as rice continues to receive precedence [37]. China's 12th Five Year Plan (2011-2015) underscores the priority of food production and processing for the Ili Kazakh Autonomous Prefecture [38] as a continuation of Beijing's overarching long-term goal of developing the west [34]. The region already supports milk and sugar processing facilities, and growth of industries based on high-value fruits and vegetables, greenhouse crops, wine grapes [39], and even lavender [40] is occurring. As a consequence, irrigation along the upper Ili is becoming more and more dependent on water from newly-constructed impoundments, the largest of which are the Zharyntaysky Reservoir on the Kash River and the Kapchagaisky Reservoir on the Tekes River [41]. These intermediate-sized reservoirs (neither is more than $25 \mathrm{~km}$ long or $5 \mathrm{~km}$ wide) and several smaller impoundments have all been constructed within the past 20 years and serve a dual purpose: they enable irrigation of nearby fields, and they also provide hydroelectricity.

\subsection{Kazakhstan}

Food production evolved much differently in Kazakhstan, especially in the thinly populated and ecologically sensitive estuary that feeds Lake Balkhash. An area with only 16,000 inhabitants [42], the delta lies within Balkanas County of Kazakhstan's Almaty Oblast. It has long attracted nomadic herders who, for centuries, brought their animals to graze on reeds and other vegetation along the river's floodplain [43]. Animal husbandry expanded significantly during the 1940s but contracted sharply following the breakup of the Soviet Union and transition to a market-based economy [14,44]. It, nevertheless, remains a viable form of agriculture in the region, with current numbers of cattle, sheep, and goats, estimated to be $39,000,23,000$, and 29,000, respectively, greatly outnumbering the delta's human inhabitants [42].

Although the Lake Balkhash fishing industry traces to the late 1920s, and so is a comparatively recent phenomenon, fish capture from the lake draws more attention than land-based agriculture in the adjacent delta $[45,46]$. Harvest was at first less than 70 tons per year and dependent on just five indigenous species: Schizothorax argentatus (Balkhash marinka), S. pseudaksaiensis (Ili marinka), Perca schrenkii (Balkhash perch), Triplophysa strauchii (spotted thicklip roach), and T. labiatus (plain thicklip roach [11]. By 1941, harvests had risen to nearly 18,650 tons annually before beginning a long decline that has accelerated recently [47]. Over the years, the lake has experienced multiple accidental and deliberate introductions of fish species. These have supplanted indigenous species to the extent that the above five species are now commercially irrelevant [48].

The 1920s ushered in a second event that was to have long lasting implications for food production along the lower reaches of the river and deeply intertwine food issues with energy. In 1926-1927, 
the Soviets dispatched a team of researchers to the basin to assess the feasibility of diverting water from the lower Ili River to facilitate cultivation of rice. They concluded that up to half a million ha were suitable for irrigation, including uncultivated desert just upstream from the estuary in the Akdala region [49]. This was hardly a novel idea. Hundreds of thousands of hectares of land adjacent to the Ili, Charyn, and smaller feeder rivers had been irrigated as early as the late nineteenth century, both for crops and forages, but by the 1920s, irrigation was entering a period of general decline [28,50].

The original 1926-1927 plan for water diversion was not immediately pursued, but an underlying concept-damming the river-was resurrected during World War II, at a time when electricity shortages were evident. As summarized in rich detail by Chida [49], who had access to original source documents, arguments for and against impounding the Ili continued until well into the 1960s. The Kapchagai dam and reservoir (not to be confused with the similarly named Kapchagaisky dam and reservoir in China) were ultimately authorized on the joint merits of increased energy and increased food. Potentially harmful downstream impacts on fisheries and animal husbandry were well known at the onset of construction in 1965, as was the likelihood that the advantages of irrigation had been overstated. However, Soviet central planners nevertheless authorized the project to proceed, with the goal of irrigating 157,000 ha of rice and 172,000 ha of vegetables, fodder, and grain crops on 65 state farms [50]. The reservoir began to fill in the fall of 1969.

Although some of the hydrological changes associated with the dam have been magnified by natural changes in the rhythm and intensity of weather cycles that preceded and then followed its construction [51], environmental concern was such that the filling of the reservoir was halted in the 1980s, when it was only half filled [11]. The environmental consequences for the delta and Lake Balkhash had become apparent shortly after the water level began to rise in the reservoir, as discharges from the dam were reduced and their seasonal periodicity adjusted to optimize power production [51]. This disrupted patterns of filtering and dramatically altered silt deposition. Nitrates, pesticides, and other pollutants from irrigated fields soon entered the river, and the delta began to contract, eventually bifurcating as the lake became more saline [52]. The lake's level dropped by $2.3 \mathrm{~m}$ between 1970 and 1987, when it reached its lowest recorded level in modern times [15,46].

Subsequent years have seen proposals to mitigate the downstream damage by adopting more efficient irrigation processes, installing dredging and ductwork, or constructing additional dams and reservoirs. Canals were constructed and a few waterways deepened as early as 1986 [14]. There was even a plan, never implemented, to sever the connection between the lake's more polluted eastern and its cleaner, Ili-fed western sections, sacrificing the former to preserve the latter [15].

It was soon evident that these hydrological perturbations would have both beneficial and detrimental impacts on food production. Although the extent of irrigation below the dam never matched projections (this would have eliminated Lake Balkhash), it eventually approached 100,000 ha with no more than 30,000 ha rendered suitable for growth of rice in rotation with other crops $[46,49,53]$. As groundwater levels around the reservoir rose, patterns of nearby crop production also shifted [54]; this and other hydrological changes led to reduced emphasis on irrigated desert areas far below the dam and increased attention to irrigation sites, such as Shengeldy, which lie just north of the impoundment $[14,49]$.

Benefits to crop-based agriculture were nonetheless offset by damaging impacts on two other key components of the food system: animal husbandry and fisheries. Two-thirds of the pastureland in the delta dried out by the early 1990s, forcing herders to drive their animals into the floodplain, where grazing inflicted further damage on an ecosystem already suffering from water shortages [55]. Kapchagai Reservoir was stocked with fish and a new fisheries industry established in 1972, but annual harvest—which ranged from 660 to 1604 tons per year between 1975 and 1991—never compensated for reduced capture in Lake Balkhash [45,54]. The lake continues to support a commercial fishing industry that, in part, relies on stocks of fingerlings from new hatcheries near the dam $[47,48]$, but sustainable harvests are estimated to be only about 7000 tons per year, and actual harvests are thought to exceed this figure by $50 \%[46,48]$. Stocking of irrigation ditches with fish has also been proposed, but poor 
water quality complicates the issue, as do management practices that reduce water levels when crops are not being grown [56].

\subsection{Ecosystem-Wide Interdependencies}

In short, the ecosystem-wide interdependencies between two water-dependent benefits-more food and more energy - are complex, culturally-anchored, and geospatially explicit, as shown in Figure $3[37,47,57,58]$. As has become evident after nearly 50 years of experience with the Kapchagai diversion project, some interactions between food and energy are predictable. When water was first withheld to fill the reservoir and create irrigated cropland, the delta and Lake Balkhash began to desiccate, just as foreseen. Controlled release of water from the impoundment to counteract the loss of the natural flood pulse $[59,60]$ partially mitigated these adverse environmental effects on animal husbandry and fisheries, but they interfered with energy production by the dam and constrained the expansion of food production onto irrigated lands. The massive, originally envisioned irrigation scheme also failed to become a reality [14], and the irrigation areas that did materialize have contracted and remain vulnerable to water deficits [32]. Attempts to fill the reservoir ceased, and it was never raised to its optimal level for energy production. Only four turbines were ultimately put into service at the dam; they run at an installed capacity of $364 \mathrm{MW}$ of power, meeting less than $2 \%$ of Kazakhstan's energy needs.

Other facets of the relationship attract less attention but are no less important. Thus, when reservoirs are created, productive food production areas along rivers are often submerged, displacing food production to less suitable areas. Irrigated croplands often replace pastures [25], and such expansion increases the demand for highly energy-intensive nitrogen fertilizers, the use of which is increasing in Central Asia [61]. Irrigation and maintenance of pastures suitable for livestock require electricity to power pumps and other infrastructure that lift and move water [62], and so factors that limit the availability or raise the price of energy often lessen food production [63]. High energy prices have, in fact, contributed to a decline in aquaculture along the Ili River in Kazakhstan [45], and in neighboring Uzbekistan, where three-quarters of the entire annual budget for the Ministry of Agriculture and Water Resources is spent on pumping water [64]. With the exception of gravity-fed areas, all of the irrigation districts fed by the Kapchagai reservoir now lie fallow, because costs to raise water from the impoundment to the agricultural fields are prohibitive. This includes areas such as Shengeldy, which lie within sight of the reservoir.

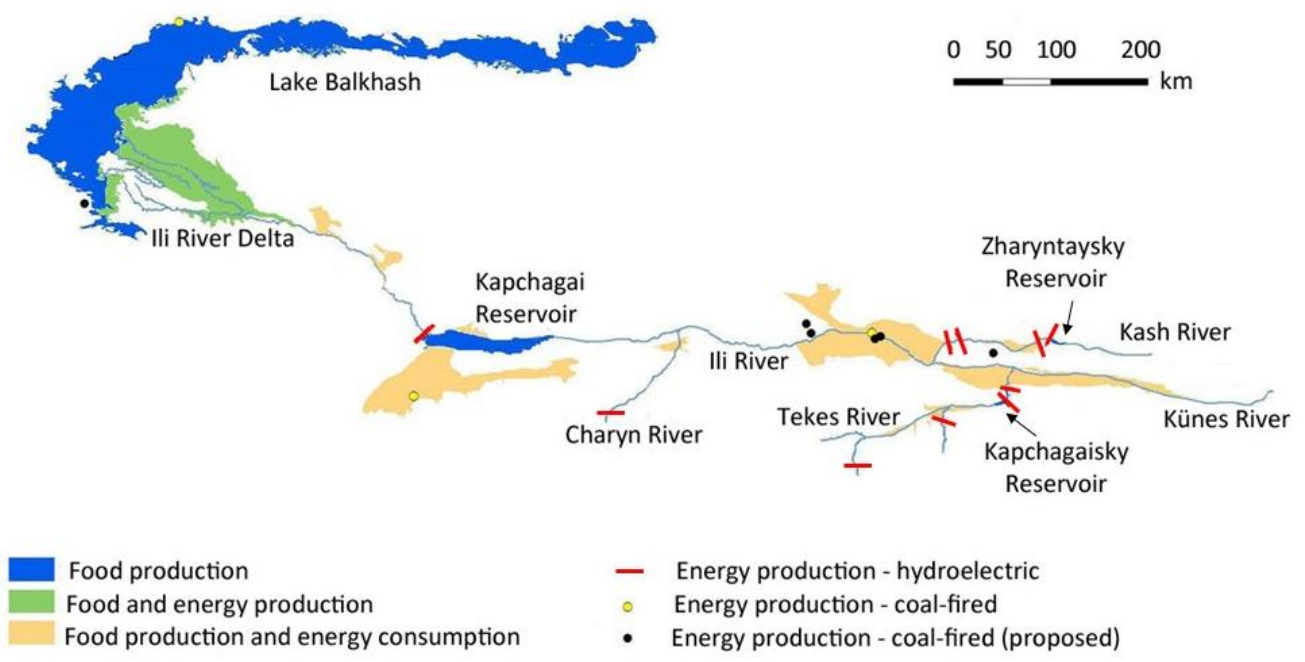

Figure 3. Geospatial relationships between energy production and consumption, food production, and water in the Ili River ecosystem. 
Changes in the water status of the delta have also led to a decline in tree cover with a corresponding increase in the extent of reed beds. Actions to generate more energy upstream have thus reduced the availability of firewood, a traditional downstream energy source, and triggered unsustainable felling of trees in the tugai [19]. Ironically, they have also led to proposals to harvest the newly-abundant reeds and manufacture briquettes that can be sold as a source of energy [65].

Reserves of petroleum and natural gas in and around China's Ili Kazakh Autonomous Prefecture are ample and slated for exploitation, yet the water implications of retrieving these fossil fuels, including possible diversion of Ili River water to other river basins, are often overlooked $[17,33,34,66-68]$. The requirements of thermal energy power plants for cooling and condensation water are significant, too, and particularly sensitive to the low water conditions that characterize the Ili River ecosystem [69,70]. Kazakhstan has ambitious plans to increase production of hydroelectric power [71]. The proposed Balkhash Thermal Power Plant is a case in point. It would consume coal from the country's Ekibastuz fields to generate $1320 \mathrm{MW}$ of power near Ulken, on the southwest shore of Lake Balkhash. Should this on again-off again project proceed, withdrawals from the lake would impose a new set of demands on water from the lower reaches of the Ili River ecosystem.

China's plans for coal-fired energy are even more ambitious [72]. Xinjiang harbors $40 \%$ of China's coal reserves [70], with rich veins underlying much of the upper Ili River valley in the expansive Ili coal basin [73]. A major coal-fired plant already in operation near Yining generates more power than the Kapchagai dam and consumes immense amounts of water, inefficiently so [74]. Although availability of cooling water is recognized to be a major constraint [70], additional thermal plants have been proposed to take advantage of the region's coal energy potential [66].

\section{Climate}

Arid and semi-arid environments are unusually and unpredictably sensitive to the effects of climate change, both beneficial and detrimental [21,75-77]. The first impacts of climate stimuli are often transmitted through the underlying hydrological system which, in the case of the Ili River ecosystem, is, for the most part, charged by precipitation and glacial meltwater from the upstream flanking ranges of the Tien Shan mountains $[3,78]$. These effects are felt temporally and spatially. Precipitation in the valley and intermontane zones that feed the upper Ili River has been increasing [2], and seasonal cycles seem to be shifting to favor more precipitation in the winter and less in the summer [3]. However, there are still no unambiguous trends in rainfall patterns, and future predictions based on climate models are uncertain and not in agreement $[21,76]$.

The consequences for the Ili River ecosystem of rising air temperatures are more straightforward. Temperatures in the region have been rising over the past half century $[3,79]$ at a rate that exceeds the regional and global average $[80,81]$ and that is predicted to elevate average annual means by 1 to 2 degrees by the middle of this century [76]. This has already occurred at the Zhaosu weather station above the Tekes River, where a 1.4-degree temperature rise over a 56-year period has been documented [23]. Although the magnitude of recorded increases declines with elevation [81], temperature is the primary factor imperiling the glaciers that supply the Ili River ecosystem with the bulk of its water [82].

Central Asia's glaciers have been retreating since the little ice age, but the rate of contraction has accelerated since the 1970s [3] and is now estimated to exceed the global average by a factor of four [83]. The ice-covered area that contributes water to the Ili River ecosystem is currently 24 to $38 \%$ smaller than in the 1960 s $[23,84,85]$. Elevated inflows of meltwater from glaciers may offer temporary downstream benefits $[3,32,86]$ and, indeed, the Ili River's flow rate has increased in recent years [14]. Expansion of glacial lakes and the unanticipated release of floodwater could, nevertheless, trigger sudden flooding and soil erosion. As the glaciers gradually disappear and lead to water deficits, the long-term consequences of glacial retreat will become uniformly detrimental as streamflow patterns are irreversibly altered $[3,87]$. 
Not all of the impacts of climate change are mediated by events in the mountains surrounding the Ili River ecosystem, and not all environmental consequences will be negative. Indeed, milder temperatures in winter, a lengthened growing season, more off-season precipitation, and plant growth-promotive effects of elevated carbon dioxide levels may enhance food production in agricultural areas at lower elevations [21]. The magnitude, spatial, and temporal aspects of these effects remain uncertain and are subjects of continued debate by climate scientists and others.

\section{Geopolitical Determinants}

If the foregoing intricacies associated with the Ili River ecosystem were not enough, Central Asia is also confronted by an unusual degree of geopolitical complexity. Uneasy interactions among the smaller, recently-independent states, and two nearby hegemons, China and Russia, impose a skein of power relationships that influence control and apportionment of water and other natural resources [88-91]. Upstream states tend to treat water as a national resource and tradable commodity, while downstream states expect to receive a fair share of what they perceive as a public good [92]. These dynamics play out against a background of disturbances that were unleashed by the dissolution of the Soviet Union. Centralized control during Soviet times, although environmentally destructive, did assure a significant degree of systems integration, and it shielded food and energy production from the vagaries of market forces [5,93]. Agricultural and hydroelectric infrastructure was installed and maintained by the state, and the use of natural resources was balanced by Moscow for the perceived common good. With independence came the collapse of the old Soviet social systems and institutions and a new emphasis on self-sufficiency in energy and food [94]. The resulting changes have been acutely felt, because the resource base needed for energy and food production is unevenly distributed across the political map $[62,89,95]$.

As the old legal framework began to dissolve and enforcement was relaxed, agriculture entered a period of decline such that by 1999, fully half of all food production in the new republics had been wiped out [96]. Yields from aquaculture facilities (some near Kapchagai Reservoir) and of fish captured in the lake were especially hard hit $[45,48]$, as lax management, insufficient regulation of water withdrawals, and overuse of water resources took their toll $[14,48,56,57,97]$. Sharp reductions in livestock numbers [28] paralleled the decline in capture fisheries, as provision of water for pastures was curtailed [98] and the newly-independent states struggled to become self-sufficient rather than specialized in the production of sheep, goats, and cattle [99]. The area of land under irrigation was also reduced as the mixture of crops growing under irrigated conditions changed $[14,17,32,37]$. Over time, lack of demand for infrastructure led to decay-especially of the extensive infrastructure required for pumping and distribution of water [47].

Although the effects of the dissolution of the USSR on the Ili River ecosystem have not abated, post-Soviet withdrawal symptoms have subsided as policy reforms have come into force $[28,100]$. This is especially true for food production in Kazakhstan, which, since 2003, has been a stated priority of the government [101]. In late 2016 Kazakhstan announced its intent to increase irrigated cropland by $45 \%$ over five years. In support of this plan, the World Bank has committed more than 340 million US dollars to improve the country's irrigation and drainage infrastructure. Food production receives similar priority in China's 12th and 13th five-year plans, which emphasize water conservation in arid regions such as that along the Ili River [38,102].

Cross-border cooperation is a logical strategy to address issues such as those surrounding the management of the Ili River ecosystem [5,42,57,58,103-106]. Indeed, China shows signs of understanding that there are linkages between its willingness to share water with Kazakhstan and the latter's willingness to provide fossil fuels and border security [107]. China has begun to invest in food and energy projects that benefit Kazakhstan, including the Moinak Hydroelectric Project on the Charyn River and the China-Kazakhstan Friendship Joint Water Diversion Project, which diverts water from the Khorgos River along their common border for hydropower and irrigation [40,89,107-110]. Progress 
in reaching a broader two-party agreement on water from the Ili River ecosystem has nevertheless been halting $[88,108,111]$.

\section{Water, Energy, and Food in the Ili River Ecosystem: A Wicked Problem}

The years following the dissolution of the USSR led to both relaxation of centralized control of water, energy, and food and to a sober assessment of the considerable environmental costs of Soviet policy $[5,17]$. This accelerated the search for other approaches to environmental management, some of which were being tested elsewhere [64,112]. Among them was the concept of Integrated Water Resources Management (IWRM), with its emphasis on coordinated management of water and related environmental resources to achieve the triple bottom line of economic, ecosystem, and social benefits [113,114]. IWRM has been embraced by international agencies and was soon applied to the Ili River ecosystem and other parts of Central Asia, but inherent difficulties with the concept, as well as a lack of regional cooperation, has impeded progress [115-119].

Several international agreements intended to facilitate regional cross-border cooperation $[5,62,103,104]$ - an admittedly difficult goal to achieve, especially in Central Asia [95] - have proven to be ineffective in enabling IWRM [118]. Alternative expert strategies, including sustainability assessment via the All Quadrants-All Levels approach [28], creation of a River Basin Vulnerability Index [24,120], and analysis within the framework of Basins at Risk $[107,121]$ have also been applied to deal with the Ili River ecosystem's complexity. Like IWRM, though, these approaches tend to be water-centric, emphasizing a single facet of a problem that is fundamentally multidimensional. When this happens, the other facets are usually de-emphasized and viewed as mere inputs or just competing uses of resources [122].

An alternative approach, the WEF nexus, has been examined as a framework to overcome the water bias, in general and specifically with respect to the Ili River ecosystem [7,10,112,113,118,119,122-125]. This approach emphasizes the interdependencies between water, energy, and food without prioritizing any component over the others. Nexus thinking is useful, because it emphasizes tradeoffs, interdependencies, and synergies between the three components (Figure 4), as well as the existence of externalities that often play out over distances and in time $[7,9]$. It draws attention to several of the thorniest challenges for the Ili River ecosystem: the ill-defined implications of climate change, lack of comprehensive coordination, the fluid and evolving status of transboundary issues, the constraints imposed by water scarcity, and the inevitable conflict in values between those seeking to exploit and those motivated to preserve the ecosystem [10,118,126-129].

The above-mentioned challenges and conflicts are characteristic of problems that have been described as "wicked" [8] or "messy" [130]. These value-laden problems are extraordinarily difficult to solve, because the core issue is dynamic and hard to define, and the surrounding conditions are evolving and often contradictory. There exist multiple potential actions, but if they lead to change in the status quo, the situation becomes only better or worse [130,131]. Since an unambiguous, readily agreed-upon right answer does not exist, the underlying problem persists. Wicked problems characterize many natural systems, including that surrounding the Ili River and Lake Balkhash (Table 1).

Although not explicitly acknowledging the Ili River ecosystem as a wicked problem, China and Kazakhstan are increasingly confronted by the interdependencies that characterize such problems:

- Finding the optimal balance among capture fisheries, aquaculture, irrigated crops, and pastures as contributors to food security;

- Balancing a portfolio of hydroelectric, thermal, and traditional energy sources;

- Responding to the spatial and temporal constraints imposed by climate change;

- Sorting out the cumulative effects of food and energy production on factors that regulate the ecology of the river, delta, and Lake Balkhash; and 
- Addressing the complex, linked issues that influence cooperation across the international border.

Table 1. The Ili River ecosystem as a wicked problem.

\begin{tabular}{ll}
\hline \multicolumn{1}{c}{ Wicked Problems Characteristic } & \multicolumn{1}{c}{ Examples from the Ili River Ecosystem } \\
\hline $\begin{array}{l}\text { Difficult to define with multiple solutions, } \\
\text { none absolutely right or wrong }\end{array}$ & $\begin{array}{l}\text { Is the main issue resource scarcity or unsustainable exploitation or } \\
\text { diversion of water? }\end{array}$ \\
\hline Societally complex with changing assumptions & $\begin{array}{l}\text { Collapse of centralized Soviet control, rise of China as an economic } \\
\text { powerhouse, disappearance of glaciers as source of water }\end{array}$ \\
\hline Tradeoffs and unexpected consequences & $\begin{array}{l}\text { Conflicting upstream and downstream priorities; water versus } \\
\text { energy versus food }\end{array}$ \\
\hline Dynamic over time with strong economic drivers & $\begin{array}{l}\text { Self-sufficiency aspirations of new Central Asian republics, China's } \\
\text { One Belt One Road initiative }\end{array}$ \\
\hline Incomplete and contradictory knowledge & $\begin{array}{l}\text { Extent of water withdrawals disputed, measurements unavailable } \\
\text { or missing }\end{array}$ \\
\hline Interconnection with other wicked problems & $\begin{array}{l}\text { Climate change; status of the internal political situation } \\
\text { in Xinjiang [132] }\end{array}$ \\
\hline
\end{tabular}

A combined approach based on the WEF nexus framework and acknowledgment of the wicked nature of the problem draws attention to two overarching questions for the Ili River ecosystem: What is the best strategy to achieve desired three-way benefits for water, energy, and food under real-world biophysical constraints and societal expectations? How can the challenges of the Ili River ecosystem best be addressed as the region's political and economic realities evolve? These questions mandate that the quest for technological solutions such as more efficient irrigation systems and new hydroelectric infrastructure be matched with sound and supportive policies, steps to avoid mismanagement, and efforts to engage local stakeholders rather than to simply impose top-down solutions [130,131,133]. Attention to the human dimension has not always been the case, as shown by past investments that have ignored the concerns of fishermen, disregard the context under which farmers operate, and failed to meet sustainability goals [49,134-138].

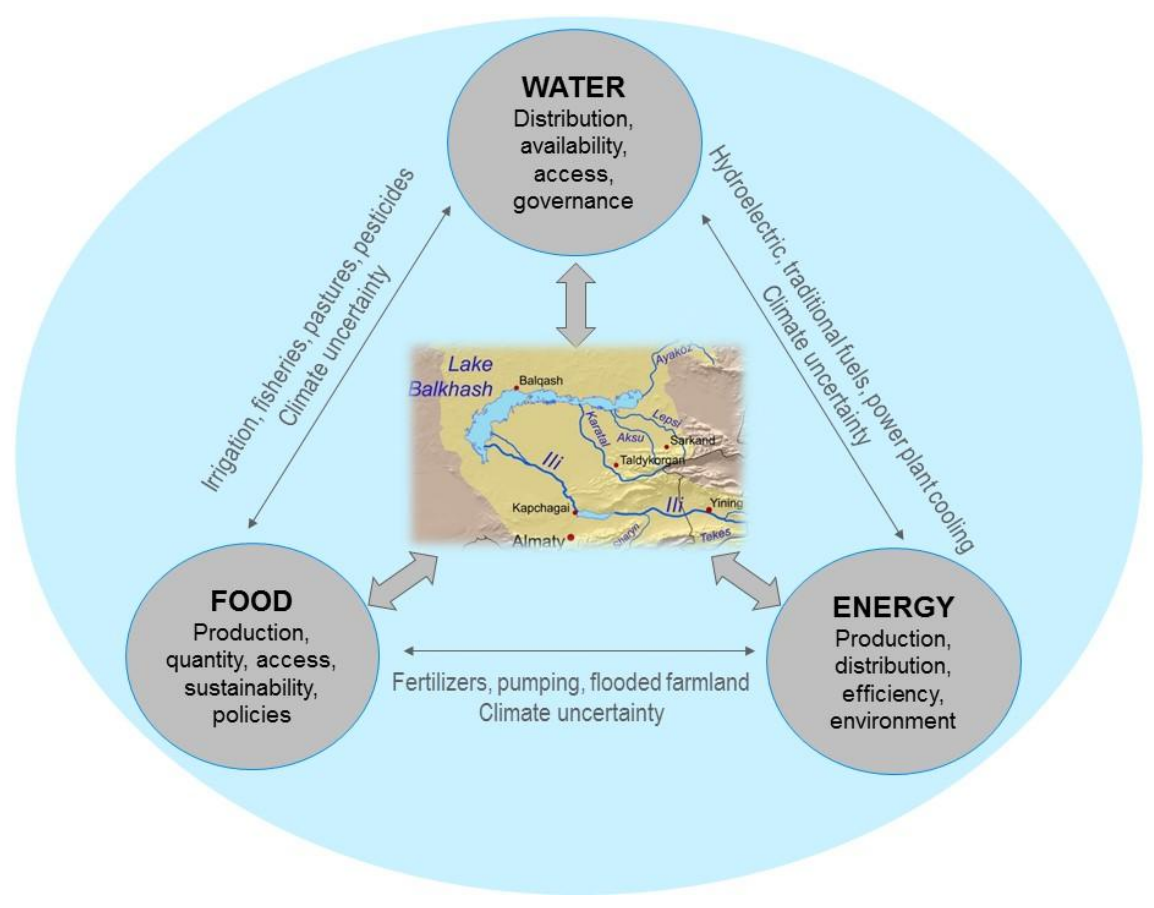

Figure 4. Schematic representation of the water-energy-food interdependencies in the Ili River ecosystem. 


\section{Framework for Bridging Knowledge Gaps}

No one would dispute the link between good data and sound environmental management, and so it should come as no surprise that the absence of such data is routinely identified as a serious constraint, in general [139,140], and specifically with respect to the Ili River ecosystem $[7,24,94,115,118]$. The challenge is not merely a question of the existence of needed data. Rather, it extends to encompass more nuanced issues: the quality and freshness of data, the extent to which they are comprehensive, whether or not data are made freely available, and the processes by which data are transformed into information and useful knowledge. Measurements from hydrological, meteorological, and related environmental monitoring facilities are a traditional point of focus for the Ili River ecosystem $[58,141,142]$. These data, which are plagued by the existence of spatial and temporal gaps $[18,28,143]$, are important, but they are clearly not sufficient. This begs related questions: What additional information is required, and what are the best ways to mobilize and guide researchers in generating it?

The Ili River ecosystem is no different from other wicked problems in that it is difficult to conceptualize data needs at scales, scopes, and in formats commensurate with whole system intricacies [64,94]. This is due in part to the inherent complexity of the problem, and in part to the fact that the ecosystem is bisected by an international border $[119,141]$. This poses severe challenges to scientific experts [144], most of whom are comfortable with discipline- and sector-specific approaches that are technical and focused on either water, energy, food, or climate. Consequently, researchers tend to further segment the problem, reducing it to a collection of subsidiary components, such as irrigation (one consumptive use of water), crops (one kind of food), or hydroelectric power (one source of energy). Such segmentation, which is often exacerbated by language and geographical isolation, is readily evident in much of the scientific literature on the Ili River ecosystem as cited here and by others $[64,112,126]$. New data are being generated from these reductionist disciplinary perspectives, but it is difficult to integrate the information and put it to good use.

Wicked problems impose another barrier to traditional scientific approaches, because they are recalcitrant to solution by the conventional linear model of science, which has data flowing from disciplinary sources into reservoirs of knowledge. These reservoirs can be tapped by those who wish to draw upon them, but this rarely leads to a solution, and so although information accumulates, the problem persists. Wicked problems are best addressed by the arduous process of posing "what ought to be" questions, rather than "what if" questions [8,145]. Contrast, for example, the difficulty of asking "what if" mean annual temperatures continue to rise and Central Asia's glaciers disappear or "what if" construction of water-intensive thermal power plants in the Ili River Valley is accelerated, with this "what ought to be" question: What is the most efficient allocation of Ili River ecosystem water among those competing to use it?

Answers to thorny "what ought to be" questions mandate that disciplinary barriers between hydrologists, agronomists, engineers, political scientists, geographers, climatologists and other specialists be surmounted, but how can this be achieved? The WEF framework provides a useful analytical approach to wicked problems by emphasizing zones of convergence between individual components of the complex underlying system, rather than the isolated individual components $[10,64,122]$. These zones define real world interdependencies, where knowledge gaps are most acute, where opportunities most likely to be found, and where single-discipline expertise are most inadequate.

Several practical tools are available to aid disciplinary experts in beginning to navigate this wicked interdisciplinary terrain. One option is to simply screen for as many interactions as can be identified at zones of convergence $[123,146]$ and then collectively assign relative priorities for investigation. Envisioning and responding to alternative ecosystem futures via scenario analysis $[129,147,148]$ is a complementary tool to break down disciplinary barriers and define possible future outcomes across the ecosystem. Table 2 identifies several knowledge gaps from the Ili River ecosystem that could be used to prime this process. 
Table 2. Key knowledge gaps, data, and analytical needs for the Ili River ecosystem.

\begin{tabular}{ll}
\hline \multicolumn{1}{c}{ Knowledge Gap } & \multicolumn{1}{c}{ Data and Analytical Needs } \\
\hline Changes in land use/land cover in the ecosystem & $\begin{array}{l}\text { Analysis and rigorous interpretation of available remote } \\
\text { sensing imagery }\end{array}$ \\
\hline $\begin{array}{l}\text { Broad consequences of changes in population size, } \\
\text { density, and resulting consumption patterns }\end{array}$ & $\begin{array}{l}\text { Demographic change data and analysis, including settlement } \\
\text { patterns in connection with measures of carrying capacity }\end{array}$ \\
\hline Ecosystem-wide impacts of dam construction & $\begin{array}{l}\text { Detailed spatial and temporal hydrological data; nutrient } \\
\text { flow measurements; modeling and simulation at the } \\
\text { ecosystem scale }\end{array}$ \\
\hline $\begin{array}{l}\text { Options for sustainable food production } \\
\text { in the ecosystem }\end{array}$ & $\begin{array}{l}\text { Pasture and cropping data series, including inputs, costs, } \\
\text { and yields; comprehensive modeling of fisheries; } \\
\text { climate projections }\end{array}$ \\
\hline $\begin{array}{l}\text { Social constraints to implementation of policy and } \\
\text { technology options }\end{array}$ & $\begin{array}{l}\text { Knowledge of stakeholder priorities and willingness/ability } \\
\text { to adopt technology; rigorous and objective policy analysis }\end{array}$ \\
\hline $\begin{array}{l}\text { Understanding of future tradeoffs between water, } \\
\text { energy, and food }\end{array}$ & $\begin{array}{l}\text { Ability to forecast based on rigorous analysis of available } \\
\text { data; scenario analysis }\end{array}$ \\
\hline
\end{tabular}

The above tools offer practical means to get started on tough, "what ought to be" questions. Each requires acknowledgment of wicked systems complexity $[145,149]$, and each can be successful only if it incorporates local, transboundary knowledge and draws upon a diverse array of scientific investigators. Previous research efforts have succeeded in merging local expertise on the Ili River, which brings tacit knowledge and strong linkages to government and other stakeholders, with specialized knowledge and independent perspectives from elsewhere [14,19,29,42,124]. Modeling and modern remote sensing technologies offer great potential to bridge information gaps efficiently across time and space, and their usefulness has already been proven in concept in Central Asia [18,41,129,150-154].

Sophisticated crop modeling methods have, for example, been validated elsewhere, and so they could be used to predict how water depletion, climate change, and societal responses to these challenges are likely to impact food production in the Ili River ecosystem $[155,156]$. Similarly, it would be possible to map and quantify spatial and temporal changes in dam site characteristics using high-resolution satellite and airborne images $[157,158]$. This, in turn, would permit measurement and simulation of the effects of water diversion on streamflow and levels of wetlands and lakes across the ecosystem [159], serving as a guide to decision-making. In light of these advances, the time seems ideal to engage a network of researchers in bridging knowledge gaps across the entire Ili River ecosystem, with emphasis on the WEF interdependencies that would ensure its preservation.

Author Contributions: S.G.P. conducted the literature review, completed the initial data analysis, and wrote the manuscript. N.A.G. and J.Q. edited the manuscript and assisted with data interpretation. S.T.N. provided data and insights from a local perspective.

Acknowledgments: The authors acknowledge the helpful suggestions of our colleagues at Michigan State University and al-Farabi Kazakh National University during the preparation of the manuscript. Special thanks to Zihan Lin for the preparation of Figures 1 and 3.

Conflicts of Interest: The authors declare no conflict of interest.

\section{References}

1. Asian Development Bank. Central Asia Atlas of Natural Resources; ADB: Manila, Philippines, 2010.

2. Sun, H.; Chen, Y.; Li, W.; Li, F.; Chen, Y.; Hao, X.; Yang, Y. Variation and abrupt change of climate in Ili River basin, Xinjiang. J. Geograph. Sci. 2010, 20, 652-666. [CrossRef]

3. Sorg, A.; Bolch, T.; Stoffel, M.; Solomina, O.; Beniston, M. Climate change impacts on glaciers and runoff in Tien Shan (Central Asia). Nat. Clim. Chang. 2012, 2, 725-731. [CrossRef]

4. World Bank Group. Turn Down the Heat; International Bank for Reconstruction and Development: Washington, DC, USA, 2014; pp. 182-188. 
5. Granit, J.; Jägerskog, A.; Lindström, A.; Björklund, G.; Bullock, A.; Löfgren, R.; de Gooijer, G.; Pettigrew, S. Regional options for addressing the water, energy and food nexus in Central Asia and the Aral Sea basin. Int. J. Water Res. Dev. 2012, 28, 419-432. [CrossRef]

6. Kostianoy, A.B.; Kosarev, A.N. (Eds.) The Aral Sea Environment; Springer: Berlin, Germany, 2010.

7. Hoff, H. Understanding the Nexus. Background Paper for the Bonn 2011 Conference; Stockholm Environment Institute: Stockholm, Sweden, 2011.

8. Batie, S. Wicked problems and applied economics. Am. J. Agric. Econ. 2008, 90, 1176-1191.

9. Guillaume, J.H.A.; Kummu, M.; Eisner, S.; Varis, O. Transferable principles for managing the nexus: Lessons from historical global water modelling in Central Asia. Water 2015, 7, 4200-4231. [CrossRef]

10. Keskinen, M.; Guillaume, J.H.A.; Kattelus, M.; Porkka, M.; Räsänen, T.A.; Varis, O. The water-energy-food nexus and the transboundary context: Insights from large Asian rivers. Water 2016, 8, 193. [CrossRef]

11. Petr, T. Lake Balkhash, Kazakhstan. Int. J. Salt Lake Res. 1992, 1, 21-46. [CrossRef]

12. Amanbayev, Z.T.; Zapparov, M.P.; Tleulesova, A.I. Integrated water resources management in the Ili-Balkhash basin. In Integrated Water Resources Management in the Ili-Balkhash Basin; Kenshimov, A.K., Ed.; United Nations Development Program: Almaty, Kazakhstan, 2011; pp. 133-143.

13. Depauw, E. Principal biomes of Central Asia. In Climate Change and Terrestrial Carbon Sequestration in Central Asia; Lal, R., Suleimenov, M., Stewart, B.A., Hansen, D.O., Doraiswamy, P., Eds.; Taylor and Francis: London, UK, 2007; pp. 3-24.

14. Dostaj, Z.D.; Giese, E.; Hagg, W. Wasserressourcen und deren Nutzung im Ili-Balchas Becken; Zentrum für Internationale Entwicklungs-und Umweltforschung der Justus-Liebig-Universität: Giessen, Germany, 2006.

15. Dostay, Z.; Alimkulov, S.; Tursunova, A.; Myrzakhmetov, A. Modern hydrological status of the estuary of Ili River. Appl. Water Sci. 2012, 2, 227-233. [CrossRef]

16. Pachikin, K.; Erokhina, O.; Funakawa, S. Soils of Kazakhstan, their distribution and mapping. In Novel Measurement and Assessment Tools for Monitoring and Management of Land and Water Resources in Agricultural Landscapes of Central Asia; Mueller, M., Saparov, A., Lischeid, G., Eds.; Springer: Cham, Switzerland, 2014; pp. 519-533.

17. Propastin, P. Problems of water resources management in the drainage basin of Lake Balkhash with respect to political development. In Climate Change and the Sustainable Use of Water Resources; Leal Filho, W., Ed.; Springer: Berlin, Germany, 2013; pp. 449-461.

18. Kezer, K.; Matsuyama, H. Decrease in river runoff in the Lake Balkhash basin in Central Asia. Hydrol. Proc. 2006, 20, 1407-1423. [CrossRef]

19. Imentai, A.; Thevs, N.; Schmidt, S.; Nurtazin, S.; Salmurzauli, R. Vegetation, fauna, and biodiversity of the Ile delta and southern Lake Balkhash-A review. J. Great Lakes Res. 2015, 41, 688-696. [CrossRef]

20. Deng, H.; Chen, Y. Influences of recent climate change and human activities on water storage variations in Central Asia. J. Hydrol. 2017, 544, 46-57. [CrossRef]

21. Lioubimtseva, E.; Henebry, G.M. Climate and environmental change in arid Central Asia: Impacts, vulnerability, and adaptations. J. Arid Environ. 2009, 73, 963-977. [CrossRef]

22. Qi, J.; Bobushev, T.S.; Kulmatov, R.; Groisman, P.; Gutman, G. Addressing global change challenges for Central Asian socio-ecosystems. Front. Earth Sci. 2012, 6, 115-121. [CrossRef]

23. Xu, J.; Liu, S.; Guo, W.; Zhang, Z.; Wei, J.; Feng, T. Glacial area changes in the Ili River catchment (Northeastern Tian Shan) in Xinjiang, China, from the 1960s to 2009. Adv. Meteorol. 2015. Available online: http:/ / dx.doi. org /10.1155/2015/847257 (accessed on 17 May 2017).

24. Varis, O.; Kummu, M. The major Central Asian river basins: An assessment of vulnerability. Int. J. Water Res. Dev. 2012, 28, 433-452. [CrossRef]

25. Moseley, G. The Ili Kazakh Autonomous Chou; Harvard University Press: Cambridge, MA, USA, 1966; 163p.

26. Wiens, H.J. Change in the ethnography and land use of the Ili Valley and region, Chinese Turkestan. Ann. Assoc. Am. Geograph. 1969, 59, 753-775. [CrossRef]

27. Noda, J. Reconsidering the Ili crisis-The Ili region under Russian Rule (1871-1881). In Reconceptualizing Cultural and Environmental Change in Central Asia: An Historical Perspective on the Future; Watanabe, M., Kubota, J., Eds.; RIHN: Kyoto, Japan, 2010; pp. 163-197.

28. Akiyama, T.; Li, J.; Kubota, J.; Konagaya, Y.; Watanabe, M. Perspectives on sustainability assessment: An integral approach to historical changes in social systems of water environment in the Ili River basin of Central Eurasia, 1900-2008. Water Futures 2012, 68, 595-627. [CrossRef] 
29. Christiansen, T.; Schöner, U. Irrigation Areas and Irrigation Water Consumption in the Upper Ili Catchment, NW-China; Zentrum für internationale Entwicklungs-und Umweltforschung der Justus-Liebig-Universität: Giessen, Germany, 2004.

30. Wang, R.; Yu, J.; Zhao, Y.; Tian, J. The main experience learned from Israel's agricultural development. Water Saving Irrig. 2010, 5, 61-63.

31. Shen, Y.; Li, S.; Chen, Y.; Qi, Y.; Zhang, S. Estimation of regional irrigation water requirement and water supply risk in the arid region of Northwestern China 1989-2010. Agric. Water Manag. 2013, 128, 55-64. [CrossRef]

32. Thevs, N.; Nurtazin, S.; Beckmann, V.; Salmyrzauli, R.; Khalil, A. Water consumption of agriculture and natural ecosystems along the Ili River in China and Kazakhstan. Water 2017, 9, 207. [CrossRef]

33. Biba, S. Desecuritization in China's behavior towards its transboundary rivers: The Mekong River, the Brahmaputra River, and the Irtysh and Ili Rivers. J. Contemp. China 2014, 23, 21-43. [CrossRef]

34. Hagt, E. China's water policies: Implications for Xinjiang and Kazakhstan. Central Asia-Caucasus Inst. Anal. 2003. Available online: http:/ / www.cacianalyst.org/?q=node/1358 (accessed on 16 May 2017).

35. Walker, K.F.; Yang, H.Z. Fish and fisheries in western China: Fish and fisheries at higher altitudes. In FAO Fisheries Technical Paper No. 385; Food and Agricultural Organization of the United Nations: Rome, Italy, 1999; pp. 237-278.

36. Yan, G. Fisheries development in Xinjiang, China. In FAO Fisheries in Irrigation Systems of Arid Asia; Petr, T., Ed.; Food and Agricultural Organization of the United Nations: Rome, Italy, 2003; pp. 95-100.

37. Bolton, K. Geopolitics of the Indo-Pacific: Emerging Conflicts, New Alliances; Black House Publishing: London, UK, 2013; pp. 99-102.

38. Liu, W.; Chen, X. The Research of Farming and Livestock Development in the Area of Ili River Valley of Xinjiang Uyghur Autonomous Region; Jiangsu Institute of Urban Planning and Design: Nanjing, China; Available online: http:/ / www.isocarp.net/Data/case_studies/2411.pdf (accessed on 17 May 2017).

39. Demei, L.I. Chinese Wine Regions; Decanter China: London, UK. Available online: https://www. decanterchina.com/en/regions/china (accessed on 24 April 2018).

40. Xinjiang's Sea of Lavender. Available online: http://www.china.org.cn/english/travel/214565.htm (accessed on 1 November 2017).

41. Spivak, L.F.; Muratova, N.R.; Vitkovskaya, I.S.; Batyrbaeva, M.Z.; Alibaev, K.U.; Moldazhanov, S.G. The results of space monitoring system of reservoirs on Ile tributaries in China. In Water Resources of Central Asia and Their Use; Institute of Geography: Almaty, Kazakhstan, 2016; pp. 424-432.

42. Thevs, N.; Beckmann, V.; Akimalieva, A.; Köbbing, J.F.; Nurtazin, S.; Hirschelmann, S.; Piechottka, T.; Salmurzauli, R.; Baibagysov, A. Assessment of ecosystem services of the wetlands in the Ili River delta, Kazakhstan. Environ. Earth Sci. 2017. [CrossRef]

43. Noda, J. Central Eurasian International Relations during the Eighteenth and Nineteenth Centuries; Brill: Leiden, The Netherlands, 2016.

44. De Beurs, K.M.; Henebry, G.M. Land surface phenology, climatic variation, and institutional change: Analyzing agricultural land cover change in Kazakhstan. Remote Sens. Environ. 2004, 89, 497-509. [CrossRef]

45. Timirkhanov, S.; Chaikin, B.; Makhambetova, Z.; Thorpe, A.; van Anrooy, R. Fisheries and Aquaculture in the Republic of Kazakhstan: A review; Food and Agricultural Organization of the United Nations: Rome, Italy, 2010.

46. Petr, T.; Mitrofanov, V.P. The impact on fish stocks of river regulation in Central Asia and Kazakhstan. Lakes Reserv. Res. Manag. 1998, 3, 143-164. [CrossRef]

47. Ismukhanov, K.; Mukhamedzhanov, V. The use of irrigation systems for sustainable production of agricultural and fish products in the Republic of Kazakhstan. In FAO Fisheries in Irrigation Systems of Arid Asia; Petr, T., Ed.; Food and Agricultural Organization of the United Nations: Rome, Italy, 2003; pp. 101-114.

48. Graham, N.A.; Pueppke, S.G.; Uderbayev, T. The current status and future of Central Asia's fish and fisheries: Confronting a wicked problem. Water 2017, 9, 701. [CrossRef]

49. Chida, T. Science, development and modernization in the Brezhnev time. The water development in the Lake Balkhash basin. Cahiers du Monde Russe 2013, 54, 239-264. [CrossRef] 
50. Barabanova, A. Discussion. In Eighth Congress of Irrigation and Drainage; Central Electronic Press: Delhi, India, 1975; Volume 2, pp. 47-49.

51. Kipshakbayev, N.K.; Abdrasilov, S.A. Effect of economic activity on the hydrologic regime and dynamics of the Ili delta. Hydrotech. Construct. 1994, 28, 416-420. [CrossRef]

52. Starodubtsev, V.M.; Truskavetskiy, S.R. Desertification processes in the Ili River delta under anthropogenic pressure. Water Resour. 2011, 38, 253-256. [CrossRef]

53. Shimizu, K.; Anzai, T.; Takahashi, N.; Kitamura, Y. An analysis on propriety of paddy rice and upland crop rotation system in the lower Ili River basin, Kazakhstan. J. Arid Land Stud. 2012, 22, 111-114.

54. Petr, T.; Mitrofanov, V.P. Fisheries in arid countries of Central Asia and in Kazakhstan under the impact of agriculture. In Papers Contributed to the Regional Symposium on Sustainable Development of Inland Fisheries under Environmental Constraints and IPFC Working Party of Experts on Inland Fisheries; Petr, T., Morris, M., Eds.; Food and Agricultural Organization of the United Nations: Rome, Italy, 1995; pp. 40-79.

55. Micklin, P.P. The Water Management Crisis in Soviet Central Asia. The Carl Beck Papers in Russian and East European Studies No. 905; University of Pittsburgh Center for Russian and East European Studies: Pittsburgh, PA, USA, 1991.

56. Petr, T. Fish stocks and fisheries irrigation systems in arid Asia. In FAO Fisheries in Irrigation Systems of Arid Asia; Petr, T., Ed.; Food and Agricultural Organization of the United Nations: Rome, Italy, 2003; pp. 1-16.

57. Laruelle, M.; Peyrouse, S. Globalizing Central Asia: Geopolitics and the Challenges of Economic Development; M. E. Sharpe: Armonk, NY, USA, 2013.

58. Libert, B.; Lipponen, A. Challenges and opportunities for transboundary water cooperation in Central Asia: Findings from UNECE's regional assessment and project work. Int. J. Water Resour. Dev. 2012, 28, 565-576. [CrossRef]

59. Junk, W.J.; Bayley, P.B.; Sparks, R.E. The flood pulse concept in river-floodplain systems. Can. Spec. Publ. Fish. Aquatic Sci. 1989, 106, 110-127.

60. Poujol, C.; Fourniau, V. Trade and economy (second half of nineteenth century to early twentieth century). In History of Civilizations of Central Asia; Palat, M.K., Tabyshalieva, A., Eds.; UNESCO Publishing: Paris, France, 2005; pp. 51-58.

61. Qushimov, J.; Ganiev, I.M.; Rustamova, I.; Haitov, B.; Islam, K.R. Land degradation by agricultural activities in Central Asia. In Climate Change and Terrestrial Carbon Sequestration in Central Asia; Lal, R., Suleimenov, M., Stewart, B.A., Hansen, D.O., Doraiswamy, P., Eds.; Taylor and Francis: London, UK, 2007; pp. 137-146.

62. Lebed, L. Possible changes in agriculture under the influence of climate change in Kazakhstan. In An Overview of Environmental Issues in Central Asia; Qi, J., Evered, K.T., Eds.; Springer: Dordrecht, The Netherlands, 2008; pp. 149-159.

63. United Nations. World Water Development Report 2014. Water and Energy; United Nations Educational, Scientific and Cultural Organization: Paris, France, 2014; Volume 2.

64. Abdullaev, I.; Rakhmatullaev, S. Setting up the agenda for water reforms in Central Asia: Does the nexus approach help? Environ. Earth Sci. 2016. [CrossRef]

65. Salmurzauly, R.; Nurtazin, S.; Yessimsiitova, Z.; Bazarbaeva, Z. Expansion of the use of natural reeds (Phragmites australis) in the delta river Ili. J. Biotechnol. 2014, 185, S66. [CrossRef]

66. Duan, J.; Wei, S.; Zeng, M.; Ju, Y. The energy industry in Xinjiang, China: Potential, problems, solutions. Power Mag. 2016. Available online: http:/ / www.powermag.com/energy-industry-xinjiang-china-potentialproblems-solutions-web / (accessed on 15 May 2017).

67. Richardson, M. China and the potential for conflict over water among Eurasian states. In Water Issues in Southeast Asia. Present Trends and Future Directions; Onn, L.P., Ed.; Institute of Southeast Asian Studies: Singapore, 2013; pp. 27-55.

68. Abishev, I.A.; Medeu, A.R.; Malkovskiy, I.M.; Toleubaeva, L.S. Water resources of Kazakhstan and their use. In Water Resources of Central Asia and Their Use; Institute of Geography: Almaty, Kazakhstan, 2016; pp. 9-18.

69. International Energy Agency. Water for energy. In World Energy Outlook 2012; IEA: Paris, France, 2012; pp. 501-528. 
70. Dorian, J.P. Central Asia: A major emerging energy player in the 21st century. Energy Policy 2006, 34, 544-555. [CrossRef]

71. Tursunov, A.A. From the Aral Lake to the Lobnor Lake: Hydrology of the Discharges of Drainage Basins of Central Asia; Galym Publishers: Almaty, Kazakhstan, 2002.

72. Endcoal. Database of Coal-Fired Plants in Operation and Planned for China's Xinjiang Uyghur Autonomous Region. Available online: endcoal.org/plant-tracker (accessed on 4 April 2017).

73. Li, J.; Zhuang, X.; Querol, X.; Font, O. Comparative study of coal qualities from three large coal basins in Xinjiang, Northwest China. Rev. Soc. Esp. Mineral. 2011, 15, 121-122.

74. Li, Z.; Amorelli, A.; Liu, P. Informing Choices for Meeting China's Energy Needs; Springer: Heidelberg, Germany, 2016.

75. Goudie, A.S. Deserts in a warmer world. In Environmental Change in Drylands: Biogeographical and Geomorphological Perspectives; Millington, A.C., Pye, K., Eds.; Wiley: New York, NY, USA, 1994; pp. 1-29.

76. Lioubimtseva, E.; Cole, R. Uncertainties of climate change in arid environments of Central Asia. Rev. Fisheries Sci. 2006, 14, 29-49. [CrossRef]

77. Melillo, J.M.; McGuire, A.D.; Kicklighter, D.W.; Moore, B., III; Vorosmarty, C.J.; Schloss, A.L. Global climate change and terrestrial net primary production. Nature 1993, 363, 234-240. [CrossRef]

78. Li, X.; Zhao, K.; Dodson, J.; Zhou, X. Moisture dynamics in central Asia for the last 15 kyr: New evidence from Ili Valley, Xinjiang, NW China. Quat. Sci. Rev. 2011, 30, 3457-3466. [CrossRef]

79. Hartmann, I. Kazakhstan. In Encyclopedia of Global Warming and Climate Change, 2nd ed.; Philander, S.G., Ed.; Sage Publications: Thousand Oaks, CA, USA, 2012; pp. 824-826.

80. Guo, L.; Li, L. Variation in the proportion of precipitation occurring as snow in the Tian Shan Mountains, China. Int. J. Climatol. 2015, 35, 1379-1393. [CrossRef]

81. Hu, Z.; Zhang, C.; Hu, Q.; Tian, H. Temperature changes in Central Asia from 1979 to 2011 based on multiple datasets. J. Clim. 2014, 27, 1143-1167. [CrossRef]

82. Aizen, V.B.; Aizen, E.M.; Melack, J.B.; Dozier, J. Climatic and hydrologic changes in the Tien Shan, Central Asia. J. Clim. 2014, 10, 1393-1404. [CrossRef]

83. Farinotti, D.; Longuevergne, L.; Moholdt, G.; Duethmann, D.; Mölg, T.; Bolch, T.; Vorogushyn, S.; Güntner, A. Substantial glacier mass loss in the Tien Shan over the past 50 years. Nat. Geosci. 2015, 8, 716-722. [CrossRef]

84. Vilesov, E.N.; Gorbunov, A.P.; Morozova, V.N.; Seversky, E.V. Degradation of the glaciation and cryogenesis of modern moraines in the northern Tien Shan. Cryosphera Zemli 2006, 10, 69-73.

85. Usmania, Z.; Shahgedanova, M.; Severskiy, I.; Nosenko, G.; Kapitsa, V. Assessment of glacier area change in the Tekes River Basin, Central Tien Shan, Kazakhstan between 1976 and 2013 using Landsat and KH-9 imagery. Cryosphere. (under review). Available online: https:/ / www.the-cryosphere-discuss.net/tc-2016-82/ (accessed on 1 November 2017).

86. Sorg, A.; Huss, M.; Rohrer, M.; Stoffel, M. The days of plenty might soon be over in glacierized Central Asian catchments. Environ. Res. Lett. 2014, 9. [CrossRef]

87. Wang, X.; Wu, K.; Jiang, L.; Liu, S.; Ding, Y.; Jiang, Z.; Guo, W. Wide expansion of glacial lakes in Tianshan mountains during 1990-2010. Acta Geogr. Sinica 2013, 68, 983-993.

88. Stucki, V.; Wegerich, K.; Rahaman, M.M.; Varis, O. Introduction: Water and security in Central Asia-Solving Rubik's cube. Int. J. Water Resour. Dev. 2012, 28, 395-397. [CrossRef]

89. Zhupankhan, A.; Tussupova, K.; Berndtsson, R. Could changing power relationships lead to better water sharing in Central Asia? Water 2017, 9, 139. [CrossRef]

90. Khamzayeva, A. Water resources management in Central Asia: Security implications and prospects for regional cooperation. In Water Resources Management in Central Asia. Regional and International Issues at Stake; Khamzayeva, A., Rahimov, S., Islamov, U., Maksudov, F., Maksudova, D., Sakiev, B., Eds.; CIBOD Foundation: Barcelona, Spain, 2009; pp. 9-32.

91. Baizakova, Z. The Irtysh and Ili Transboundary Rivers: The Kazakh-Chinese Path to Compromise. Available online: http:/ / centralasiaprogram.org/archives/7374 (accessed on 9 January 2018).

92. Chellaney, B. Water, Peace, and War. Confronting the Global Water Crisis; Rowman \& Littlefield: Lanham, MD, USA, 2013.

93. Wegerich, K. Water resources in Central Asia: Regional stability or patchy make-up? Central Asian Surv. 2011, 2, 275-290. [CrossRef] 
94. Abdullaev, I.; Rakhmatullaev, S. Data management for integrated water resources management in Central Asia. J. Hydroinform. 2014, 16, 1425-1440. [CrossRef]

95. Boute, A. The water-energy-climate nexus under international law: A Central Asian perspective. Michigan J. Environ. Law 2016, 5, 371-434.

96. Paroda, R. Addressing challenges for sustainable agriculture in Central Asia. In Climate Change and Terrestrial Carbon Sequestration in Central Asia; Lal, R., Suleimenov, M., Stewart, B.A., Hansen, D.O., Doraiswamy, P., Eds.; Taylor and Francis: London, UK, 2007; pp. 109-126.

97. Pueppke, S.G.; Iklasov, M.K.; Beckmann, V.; Nurtazin, S.T.; Thevs, N.; Sharakhmetov, S.; Hoshino, B. Challenges for sustainable use of the fish resources from Lake Balkhash, a fragile lake in an arid ecosystem. Sustainability 2018, 10, 1234. [CrossRef]

98. Bazarbayev, A.T.; Bayekenova, M.K. The challenge of water provision for pasture lands: A restrictive factor for livestock breeding development in Kazakhstan. In An Overview of Environmental Issues in Central Asia; Qi, J., Evered, K.T., Eds.; Springer: Dordrecht, The Netherlands, 2008; pp. 201-208.

99. Suleimenov, M.; Iniguez, L.; Mursayeva, M. Policy reforms and livestock development in Central Asia. In Policy Reforms and Agricultural Development in Central Asia; Babu, S.C., Djalalov, S., Eds.; Springer: New York, NY, USA, 2006; pp. 277-310.

100. Lerman, Z. Agricultural recovery in the former Soviet Union: An overview of 15 years of land reform and farm restructuring. Post-Communist Econ. 2008, 20, 391-412. [CrossRef]

101. Organization for Economic Cooperation and Development. OECD Review of Agricultural Policies: Kazakhstan; OECD Publishing: Paris, France, 2013.

102. Central Committee of the Communist Party of China. The 13th Five Year Plan for Economic and Social Development of the People's Republic of China (2016-2020); Compilation and Translation Bureau, Central Committee of the Communist Party of China: Beijing, China, 2016.

103. Eritja, M.C.; Estapa, J.S.; Rafols, X.P. Towards improved regional co-operation over water uses in Central Asia: The case of hydroelectric energy and inland fisheries. Asian J. Int. Law 2016, 6, 119-158. [CrossRef]

104. Rahaman, M.M. Principles of transboundary water resources management and water-related agreements in Central Asia: An analysis. Int. J. Water Resour. Dev. 2012, 28, 475-491. [CrossRef]

105. Stone, R. Transboundary rivers for China and Kazakhstan, no meeting of the minds on water. Science 2012, 337, 405-407. [CrossRef] [PubMed]

106. Feng, Y.; He, D. Transboundary water vulnerability and its drivers in China. J. Geogr. Sci. 2009, 19, 189-199. [CrossRef]

107. Ho, S. China's transboundary river policies towards Kazakhstan: Issue-linkages and incentives for cooperation. Water Int. 2017, 42, 142-162. [CrossRef]

108. Peyrouse, S. The hydroelectric sector in Central Asia and the growing role of China. China Eurasia Forum Quart. 2007, 5, 131-148.

109. Li, Z.; Wu, F. China and shared water resources. Geopolitics, domestic institutions and global government. In China's Global Quest for Resources. Energy, Food and Water; Wu, F., Zhang, H., Eds.; Routledge: Abingdon, UK, 2017; pp. 59-78.

110. United Nations Development Programme. Intergovernmental Water Relations in Ile-Balkhash Basin; UNDP Regional Center for Europe and China: Almaty, Kazakhstan, 2011; Available online: http:/ / centralasia.iwlearn.org/publications/projectdocuments/national-component-in-kazakhstan/ intergovernmental-water-relations-in-the-ili-balkhash-basin (accessed on 24 April 2018).

111. Ibrayev, T.; Badjanov, B.; Li, M. Methodology of measuring processes and evaluation of water resources of the Republic of Kazakhstan. In Novel Measurement and Assessment Tools for Monitoring and Management of Land and Water Resources in Agricultural Landscapes of Central Asia; Mueller, L., Saparov, A., Lischeid, G., Eds.; Springer: Heidelberg, Germany, 2013; pp. 563-575.

112. Mueller, L.; Suleimenov, M.; Karimov, A.; Qadir, M.; Saparov, A.; Balgabayev, N.; Helming, K.; Lischeid, G. Land and water resources of Central Asia, their utilization and ecological status. In Novel Measurement and Assessment Tools for Monitoring and Management of Land and Water Resources in Agricultural Landscapes of Central Asia; Mueller, L., Saparov, A., Lischeid, G., Eds.; Springer: Heidelberg, Germany, 2013; pp. 3-59.

113. Benson, D.; Gain, A.K.; Rouillard, J.J. Water governance in a comparative perspective: From IWRM to a 'nexus' approach? Water Altern. 2015, 8, 756-773. 
114. Zinzani, A. Irrigation management transfer and WUAs' dynamics: Evidence from the South-Kazakhstan Province. Environ. Earth Sci. 2015, 73, 765-777. [CrossRef]

115. Sokolov, V. Experiences with IWRM in the Central Asia and Caucasus regions. Water Int. 2006, 31, 59-70. [CrossRef]

116. Biswis, A.K. Integrated water resources management: A reassessment. Water Int. 2004, 2, 248-256. [CrossRef]

117. Groll, M.; Opp, C.; Kulmatov, R.; Ikramova, M.; Normatov, I. Water quality, potential conflicts and solutions-an upstream-downstream analysis of the transnational Zarafshan River (Tajikistan, Uzbekistan). Environ. Earth Sci. 2015, 73, 743-763. [CrossRef]

118. Keskinen, M.; Varis, O. Water-energy-food nexus in large Asian river basins. Water 2016, 8, 446. [CrossRef]

119. Allouche, J.; Middleton, C.; Gyawali, D. Technical veil, hidden politics: Interrogating the power linkages behind the nexus. Water Altern. 2015, 8, 610-626.

120. Varis, O.; Kummu, M.; Salmivaara, A. Ten major rivers in monsoon Asia-Pacific: An assessment of vulnerability. Appl. Geogr. 2012, 32, 441-454. [CrossRef]

121. Wolf, A.T.; Yoffe, S.B.; Giordano, M. International Water Law: Indicators for Identifying Basins at Risk; UNESCO: Paris, France, 2003.

122. Bazilian, M.; Rogner, H.; Howells, M.; Hermann, S.; Arent, D.; Gielen, D.; Steduto, P.; Mueller, A.; Komor, P.; Tol, R.S.J.; et al. Considering the energy, water and food nexus: Towards an integrated modelling approach. Energy Policy 2011, 39, 7896-7906. [CrossRef]

123. Villiamayo-Tomas, S.; Grundmann, P.; Epstein, G.; Evans, T.; Kimmich, C. The water-energy-food security nexus through the lenses of the value chain and the institutional analysis and development frameworks. Water Altern. 2015, 8, 735-755.

124. Muller, M. The 'Nexus' as a step back towards a more coherent water resource management paradigm. Water Altern. 2015, 8, 675-694.

125. Albrecht, T.R.; Crootof, A.; Scott, C.A. The water-energy-food nexus: A systematic review of methods for nexus assessment. Environ. Res. Lett. 2018, 13. in press. [CrossRef]

126. Maas, A.; Issayeva, G.; Rüttinger, K.; Umirbekov, A. Climate Change and the Water-Energy-Agriculture Nexus in Central Asia; Adelphi Research: Berlin, Germany, 2012.

127. Bach, H.; Bird, J.; Clausen, T.J.; Jensen, K.M.; Lange, R.B.; Taylor, R.; Viriyasakultorn, V.; Wolf, A. Transboundary River Basin Management: Addressing Water, Energy and Food Security; Mekong River Commission: Vientiane, Laos, 2012.

128. Olsson, G. Water, energy and food interactions-Challenges and opportunities. Front. Environ. Sci. Eng. 2013, 7, 787-793. [CrossRef]

129. Baubekova, A. Integrated Modeling in Support of Transboundary Water Cooperation in Central Asia: Ili-Balkhash Watershed. Master's Thesis, Central European University, Budapest, Hungary, 2014.

130. Pahl-Wostl, C. The importance of social learning in restoring multifunctionality of rivers and floodplains. Ecol. Soc. 2006, 11, 10. Available online: http://www.ecologyandsociety.org/vo111/iss1/art10 (accessed on 3 April 2018). [CrossRef]

131. Pahl-Wostl, C. A conceptual framework for analyzing adaptive capacity and multi-level learning processes in resource governance regimes. Glob. Environ. Chang. 2009, 19, 354-365. [CrossRef]

132. Kaup, K. China, ethnic conflict in the world's largest multinational state. In Encyclopedia of Modern Ethnic Conflicts, 2nd ed.; Rudolph, J.R., Jr., Ed.; ABC-CLIO: Santa Barbara, CA, USA, 2016; Volume 1, pp. 99-118.

133. Pahl-Wostl, C. Transitions towards adaptive management of water facing climate and global change. Water Res. Manag. 2007, 21, 49-62. [CrossRef]

134. Implementation Completion Report on a Loan in the Amount of US $\$ 80$ Million to the Republic of Kazakhstan for an Irrigation and Drainage Improvement Project. Available online: http:/ / documents.worldbank.org/ curated/en/798361468038343156/pdf/316480rev.pdf (accessed on 9 March 2018).

135. Narbayev, T.; Zauerbek, A.K.; Narbayev, M.; Narbayeva, K. Improvement of the methodology and scientific-technical basis of the adjustment parameters of reservoirs in the pool of undrained rivers (case study of Ile River basin). News Nat. Acad. Sci. Rep. Kazakhstan Ser. Geol. Tech. Sci. 2017, 3, 100-113.

136. Barrett, T.; Feola, G.; Khusnitdinova, M.; Krylova, V. Adapting agricultural water use to climate change in a post-Soviet context: Challenges and opportunities in Southeast Kazakhstan. Hum. Ecol. 2017, 45, 747-762. [CrossRef] [PubMed] 
137. Mukhtarov, F. Translating water policy innovations into Kazakhstan: The importance of context. In Water Governance, Policy and Knowledge Transfer: International Studies on Contextual Water Management; De Boer, C., Vinke-de Kruijf, J., Özerol, G., Bressers, H.T.A., Eds.; Routledge: London, UK, 2013; pp. 113-127.

138. Project Appraisal Document on a Proposed Loan in the Amount of US\$102,902,440 to the Republic of Kazakhstan for a Second Irrigation and Drainage Improvement Project. Available online: http: / documents. worldbank.org/curated/en/917891468272048966/pdf/PAD2920P086592010Box377346B00OUO090.pdf (accessed on 9 March 2018).

139. Miller, T.R. Constructing sustainability science: Emerging perspectives and research trajectories. Sustain. Sci. 2013, 8, 279-293. [CrossRef]

140. Spangenberg, J.H. Sustainability science: A review, an analysis and some empirical lessons. Environ. Conserv. 2011, 38, 275-287. [CrossRef]

141. McDonnell, R.A. Challenges for integrated water resources management: How do we provide the knowledge to support truly integrated thinking? Int. J. Water Res. Dev. 2008, 24, 131-143. [CrossRef]

142. Ibrabaev, T.; Badjanov, B.; Li, M. Long-term monitoring and water resource management in the Republic of Kazakhstan. In Novel Measurement and Assessment Tools for Monitoring and Management of Land and Water Resources in Central Asia; Mueller, L., Saparov, A., Lischeid, G., Eds.; Springer: Heidelberg, Germany, 2013; pp. 75-89.

143. Propastin, P. Remote Sensing Based Study on Vegetation Dynamics in Drylands of Kazakhstan. Ph.D. Thesis, Georg-August-Universität, Göttingen, Germany, 2006.

144. Brunson, M.W.; Baker, M.A. Translational training for tomorrow's environmental scientists. J. Environ. Stud. Sci. 2016, 6, 295-299. [CrossRef]

145. Benda, L.; Poff, N.L.; Tague, C.; Palmer, M.A.; Pizzuto, J.; Cooper, S.; Stanley, E.; Moglen, G. How to avoid train wrecks when using science in environmental problem solving. BioScience 2002, 52, 1127-1136. [CrossRef]

146. Propastin, P. Assessment of climate and human induced disaster risk over shared water resources in the Balkhash Lake drainage basin. In Climate Change and the Sustainable Use of Water Resources; Leal Filho, W., Ed.; Springer: Berlin, Germany, 2013; pp. 41-54.

147. Weitz, N. Cross-Sectoral Integration in the Sustainable Development Goals: A Nexus Approach; Stockholm Environment Institute: Stockholm, Sweden, 2014.

148. Bizikova, L.; Roy, D.; Swanson, D.; Venema, H.D.; McCandless, M. The Water-Energy-Food Security Nexus: Towards a Practical Planning and Decision-Support Framework for Landscape Investment and Risk Management; International Institute for Sustainable Development: Winnipeg, MB, Canada, 2013.

149. Hall, T.E.; O'Rourke, M. Responding to communication challenges in transdisciplinary sustainability science. In Heuristics of Transdisciplinary Sustainability Studies: Solution-Oriented Approaches to Complex Problems; Huutoniemi, K., Tapio, P., Eds.; Routledge: Oxford, UK, 2014; pp. 119-139.

150. Celis, D.; De Pauw, E.; Geerken, R. Assessment of Land Cover and Land Use in Central and West Asia and North Africa. Part 2. Hot Spots of Land Cover Change and Drought Vulnerability; International Center for Agricultural Research in Dry Areas: Aleppo, Syria, 2007.

151. Kappas, M.; Propastin, P. Monitoring and assessment of dryland ecosystems with remote sensing. In Dryland East Asia: Land Dynamics Amid Social and Climate Change; Chen, J., Wan, S., Henebry, G., Qi, J., Gutman, G., Sun, G., Kappas, M., Eds.; DeGruyter Higher Education Press: Berlin, Germany, 2014; pp. 311-349.

152. Lebed, L.; Qi, J.; Heilman, P. Monitoring rangeland ecosystems with remote sensing: An example from Kazakhstan. In An Overview of Environmental Issues in Central Asia; Qi, J., Evered, K.T., Eds.; Springer: Dordrecht, The Netherlands, 2008; pp. 135-146.

153. Pflugmacher, D.; Krankina, O.N.; Cohen, W.B.; Friedl, M.A.; Sulla-Menashe, D.; Kennedy, R.E.; Nelson, P.; Loboda, T.V.; Kuemmerle, T.; Dyukarev, E.; et al. Comparison and assessment of coarse resolution land cover maps for Northern Eurasia. Remote Sens. Environ. 2011, 115, 3539-3553. [CrossRef]

154. Propastin, P.; Kappas, M.; Muratova, N.R. A remote sensing based monitoring system for discrimination between climate and human-induced vegetation change in Central Asia. Manag. Environ. Qual. 2008, 19, 579-596. [CrossRef]

155. Cotterman, K.A.; Kendall, A.D.; Basso, B.; Hyndman, D.W. Groundwater depletion and climate change: Future prospects of crop production in the Central High Plains aquifer. Clim. Chang. 2017. [CrossRef] 
156. Basso, B.; Hyndman, D.W.; Kendall, A.D.; Grace, P.R.; Robertson, G.P. Can impacts of climate change and agricultural adaptation strategies be accurately quantified if crop models are annually re-initialized? PLoS ONE 2015. [CrossRef] [PubMed]

157. Van Dijk, A.I.J.M.; Renzullo, L.J. Water resource monitoring systems and the role of satellite observations. Hydrol. Earth Syst. Sci. 2011, 15, 39-55. [CrossRef]

158. Torbick, N.; Chowdhury, D.; Salas, W.; Qi, J. Monitoring rice agriculture across Myanmar using time series Sentinel-1 assisted by Landsat-8 and PALSAR-2. Remote Sens. 2017, 9. [CrossRef]

159. Hyndman, D.W.; Kendall, A.D.; Welty, N.R.H. Evaluating temporal and spatial variations in recharge and streamflow using the integrated landscape hydrology model (ILHM). Subsurf. Hydrol. Data Integ. Prop. Process. 2007, 171, 121-141.

(C) 2018 by the authors. Licensee MDPI, Basel, Switzerland. This article is an open access article distributed under the terms and conditions of the Creative Commons Attribution (CC BY) license (http:/ / creativecommons.org/licenses/by/4.0/). 